\title{
The late Neogene-early Quaternary small vertebrate succession from the Almenara-Casablanca karst complex (Castellón, Eastern Spain): Chronologic and paleoclimatic context
}

\author{
Jordi Agustía, ${ }^{\mathrm{a}, *}$, Andrés Santos-Cubedo ${ }^{\mathrm{b}}$, Marc Furió $^{\mathrm{b}}$, Roger De Marfá ${ }^{\mathrm{c}}$, Hugues-Alexandre Blain $^{\mathrm{d}}$, \\ Oriol Oms ${ }^{\mathrm{e}}$, Paloma Sevilla ${ }^{\mathrm{f}}$ \\ a ICREA, Institut de Paleoecologia Humana i Evolució Social, Universitat Rovira i Virgill, Plaça Imperial Tarraco 1, E-43005 Tarragona, Spain

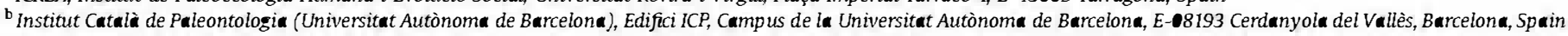 \\ ${ }^{c}$ Departament d'Estratigrafia, Paleontologia $i$ Geociències Marines, Universitat de Barcelona, $c /$ Martí $i$ Franquès $s / n, E$ - $\mathbf{0} \mathbf{2 8}$ Barcelona, Spain \\ ${ }^{d}$ Institut de Paleoecologia Humana $i$ Evolució Sociai, Universitat Rovira $i$ Virgill, Plaça Imperial Tarraco 1, E-43005 Tarragona, Spain \\ e Departament de Geologia, Universitat Autònoma de Barcelona, 08193 Bellaterra, Spain \\ ' Departamento de Paleontología, Facultad de Ciencias Geológicas (UCM) e Instituto de Geología Económica (CSIC), C/ José Antonio Novais 2, 28๑4๑ Madrid, Spain
}

\begin{abstract}
A B S T R A C T
Although discontinuous because of their karst nature, the Almenara-Casablanca complex records a very complete small vertebrate succession (amphibians, squamates, insectivores, bats, rodents and lagomorphs), characterized by the richness of their sites, a richness which cannot be expected in sites of fluvio-lacustrine origin. This late Neogene-early Quaternary succession includes the sites of AlmenaraCasablanca M (Miocene-Pliocene boundary), Almenara-Casablanca 4 (late Pliocene), Almenara-Casablanca 1 (earliest Pleistocene) and Almenara-Casablanca 3 (late early Pleistocene). In this way, the Almenara-Casablanca succession complements the data from other well know terrestrial PliocenePleistocene sequences in the Iberian Peninsula, most notably that of the Guadix-Baza Basin. The complementation between the almost continuous Pliocene-Pleistocene sequence of the Guadix-Baza Basin and the discontinuous but very rich succession from the Almenara-Casablanca complex enables accurate dating of some of the faunal events that punctuate the Pliocene-early Pleistocene time interval. Furthermore, the assemblages from the Almenara-Casablanca complex contain the evidence of the earliest occurrences of several taxa as well as the persistence of other that had already disappeared from other European regions. Therefore, it provides new evidence for the particular role which the Iberian Peninsula played during the late Neogene and early Quaternary, acting at certain moments as a bridge for the entry of African taxa or, alternatively, as a refuge for other European taxa. This paper provides an updated review of the small vertebrate succession from this complex.
\end{abstract}

\section{Introduction}

The Almenara-Casablanca karst complex is located in an abandoned quarry next to the town of Almenara (Castellón, Spain) $30 \mathrm{~km}$ north of the city of Valencia, in the eastern sector of the Iberian range (Fig. 1). The promontory, known as Muntanya Blanca, belongs to the coastal ends of Sierra de Espadan range, and it is within a few kilometres of the present Mediterranean coast. The paleokarst developed on limestones of middle Triassic age and led

\footnotetext{
* Corresponding author.

E-mail address: jordi.agusti@icrea.es (J. Agustí)
}

to the formation of a number of fissure infillings, some of them displaying rich vertebrate assemblages including small and large vertebrates (Agustí and Galobart, 1986; Agustí et al., 1987). The set of localities were discovered in 1982 by a team of the Servei Investigacions Arqueològiques Provincials (SIAP) coordinated by F. Gusi. In 1983 a first digging campaign was coordinated by F. Gusi and E. Carbonell. Afterwards, during 1984, 1985 and 1986 the complex was excavated by a joint team of the SIAP and the Institut de Paleontologia M. Crusafont from Sabadell. Most of the fossiliferous outcrops are of Pliocene-Pleistocene age, but the oldest one (Almenara-Casablanca $\mathrm{M}$ ) can be dated back to the latest Miocene. The Plio-Pleistocene succession includes the sites of AlmenaraCasablanca 4 (late Pliocene), Almenara-Casablanca 1 (earliest Pleistocene) and Almenara-Casablanca 3 (late early Pleistocene). 

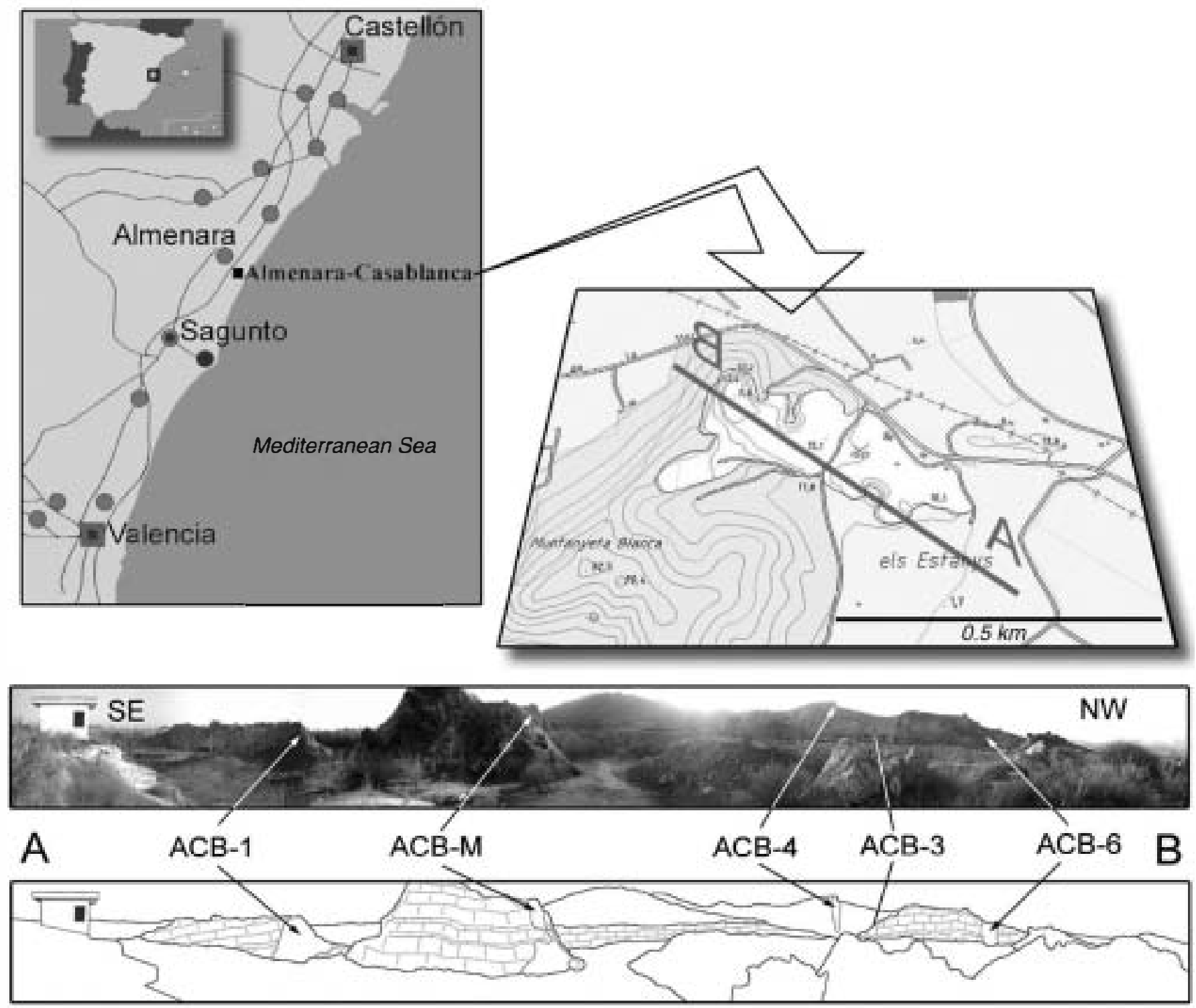

Fig. 1. Geographical location of the karst complex of Almenara-Casablanca with the reference of the different sites inside the outcrop (Castellón, eastern Spain).

\section{Almenara-Casablanca M (ACB M, latest Miocene)}

This site, originally referred to as "Casablanca 2", was first sampled in 1983. It is formed of yellowish clays which contained abundant bone fragments. Sieving of several tones of sediment led to the recovery of a rich small mammal assemblage (Tables 1 and 2) which is mainly composed of murids (Apodemus gudrunae, Occitanomys cf. adroveri, Castillomys crusafonti, Paraethomys meini, Stephanomys ramblensis), cricetids (Ruscinomys lasallei, Apocricetus alberti, Blancomys sp.) and glirids (Eliomys truci; Agustí and Galobart, 1986; Agustí, 1989, 1990; Agustí and Casanovas-Vilar, 2003). This assemblage clearly corresponds to the latest Miocene (MN 13), therefore indicating a karstification phase much older than the other fissure infillings from the complex. Even more surprising was the fact that this typical late Miocene assemblage included a number of rodent species of African and Asian affinities, such as the myocricetodontines Myocricetodon jaegeri and Calomyscus sp., and the gerbils Debruijnimys almenarensis and Pseudomeriones abbreviatus (Agustí, 1989, 1990, 1991; Agustí and Casanovas-Vilar, 2003). The presence of Pseudomeriones abbreviatus is particularly significant, since this species was originally described from China, and no previous European record existed. Unfortunately, insectivores are quite rare and only include Parasorex cf. ibericus and Blarinella cf. europaea (Furió, 2007a). The crocidurinae quoted in previous faunal lists (e.g., Van den Hoek Ostende and Furió, 2005) probably corresponds to contamination with sub-recent material (Furió, 2007b). The few recovered large mammals also show the same mixture of European, Asian and possible African elements: Felidae indet., cf. Nyctereutes, Pliohyrax graecus, Bovidae indet. and Macaca sp. (Agustí and Galobart, 1986; Pickford et al., 1997; Köhler et al., 2000). Macaca sp. corresponds to the earliest occurrence of this genus.

Levels equivalent to Almenara-Casablanca $M$ are recorded in the Negratín series, in the Guadix sub-basin. As in the case of ACB M, the small mammalian fauna from Negratín 1 is characterized, among other elements in common, by the presence of rodents of African origin (Myocricetodon jaegeri and Debruijnimys almenarensis; Minwer-Barakat et al., 2009). Debruijnimys almenarensis has been also found in the continental deposits at the base of the Zorreras Member, in the Sorbas Basin (SE Spain; Martín-Suárez et al., 2000). These continental deposits show reverse polarity and are overlain by marine deposits of early Pliocene age, referred 

and Negratín 1.

The presence of Asian and African elements at Almenara-Casablanca $\mathrm{M}$ can be explained on the basis of the set of events associated with the Messinian Salinity Crisis (MSC), between 5.6 and $5.32 \mathrm{Ma}$ (Krijgsman et al., 1999). This crisis involved the desiccation of the Mediterranean and the opening of new intercontinental routes between the two margins of the basin, therefore enhancing the exchange of terrestrial faunas (Agustí and Llenas, 1996; Agustí et al., 2006). The abundance of gerbils probably indicates the presence at that time of very dry, sub-desert conditions in the area. This is also confirmed by the low insectivore diversity.

\section{Almenara-Casablanca 4 (ACB 4, late Pliocene)}

This site was originally published as Casablanca $\mathbf{B}$ by Gil and Sesé (1985). Later, further samplings by a joint team of the SIAP and the Institut de Paleontologia M. Crusafont led also to the recovery of large mammals in this site. Originally, an age equivalent to the site of Almenara-Casablanca 1 (ACB 1) was proposed (Gil and Sesé, 1985; Agustí and Galobart, 1986), therefore assigning Almenara-Casablanca 4 to the MN 17 unit (now, earliest Pleistocene). In 2004 new excavations headed by A. Santos-Cubedo and M. Furió led to a considerable enlargement of the list of small and large mammals. As a result of these new excavations, it was documented the oldest record of the Eurasian badger Meles (Madurell-Malapeira et al., 2009). A second immediate benefit was the analysis of a much larger sample of rodents, which indicated a late Pliocene age (MN 16), as shown by the less derived features of Kislangia aff. cappettai from this site with respect to Kislangia gusii from ACB 1 . Besides Kislangia, other rodent species include Stephanomys progressus, Castillomys crusafonti, Apodemus aff. mystacinus, Apodemus sp. and Eliomys aff. intermedius (Table 1).

The insectivores are represented by Desmana inflata, Talpa cf. fossilis, Myosorex meini, Deinsdorfia doukasi and Sorex minutus (Furió, 2007a; Furió et al., 2007; Furió and Mein, 2008). The insectivore assemblage is largely dominated by the white-toothed crocidosoricine shrew Myosorex. The arrival of Deinsdorfia to Spain was probably related with the climatic changes that took place at the Ruscinian-Villanyian boundary (Furió and Mein, 2008). Chiroptera are very diverse and include up to 12 species of the genera Rhinolophus, Myotis, Plecotus, Eptesicus, Pipistrellus and Miniopterus. In this assemblage, rhinolophids are the dominant bats, the middlesized rhinolophid Rhinolophus euryale being the most abundantly represented. Among the vespertilionids, Miniopterus is the best represented genus, though its remains are less common than in ACB 1. The remaining vespertilionids are represented by few remains (Table 2 ).

The fauna of amphibians and squamates is also very diverse (Table 3), including anurans (Discoglossus, Pelobates, Pelodytes, Bufo and Pelophylax), amphisbaenids (Blanus cinereus), agamids, gekkonids (Tarentola), lacertids, anguids (Dopasia), colubrids (Coronella and Malpolon) and viperids (Vipera). The presence of Malpolon monspessulanus at ACB4 documents a very early, late Pliocene presence of this African colubrid in the Iberian Peninsula. This species is also cited from the Pliocene and early Pleistocene of France (Bailon, 1991a,b). This evidence contradicts previous ideas based on genetic analysis which assumed a late Pleistocene entry of this species, following a moment of low sea level (Carranza et al., 2006), although these authors do not excluded the possibility of earliest colonization waves from Africa to Europe.

Concerning Dopasia, note that it is used in this work sensu Augé (2005), that considers that all Eurasian and African species (excluding Pseudopus) pertains to genus Dopasia and can be 
stated that a detailed study was required to understand the genesis and geometry of the stratigraphic record. The stratigraphy of the site appeared to be a complicated one due to the noncontinuity and irregularities of strata and reworking as well. Although the whole outcrop is rather small, these authors stated that important lateral changes are observed between the north and south outcrops. Ginés and Pons Moyà (1986), Agustí and Galobart (1986) and Agustí (1990) have successively revised and simplified the stratigraphy. Esteban Aenlle and López Martínez (1987) used a stratigraphy by 'Carbonell and Martinez' (not referred to in the work) which also displays a simple succession of strata. The recent observation of the section does not allow improvement of any previous study. From examination of the pictures of the outcrops in Ginés and Pons Moyà (1986), the present outcrops are far more weathered and covered by regolith. In any case, the stratigraphy is rather clear for the upper half of the section.

The detailed understanding of Almenara-Casablanca 1 stratigraphy is beyond the scope of this paper, but an attempt to integrate existing data is provided in Fig. 2. Above the blocks shown in Fig. 2 (from $5.5 \mathrm{~m}$ upwards), the succession is simple. According to the available literature, this succession starts from level 8 of Esteban Aenlle and López Martínez (1987), level Y of Agustí and Galobart (1986) and level N4 of Agustí (1990). The small mammal assemblage includes a highly diversified rodent association, mainly composed of arvicolids and murids. Arvicolids are represented by three different species (Kislangia gusii, Mimomys medasensis and Mimomys (Tcharinomys) tornensis; Esteban-Aenlle and LópezMartínez, 1987; Agustí et al., 1993b), which is also the case for murids (Stephanomys progressus, Apodemus cf. mystacinus, Castillomys crusafonti). In the upper levels of this site, Kislangia gusii and Mimomys (Tcharinomys) tomensis are already absent (Gil and Sesé, 1984), perhaps indicating the last occurrence of these two arvicolids. Moreover, Stephanomys progressus is represented by one of the most derived populations of the genus Stephanomys, and it probably marks the last occurrence of this taxon as well. The rodent association is completed by Eliomys quercinus and Sciurinae indet (Table 1).

Lagomorphs include Prolagus calpensis and Oryctolagus sp. The third upper premolar $\left(\mathrm{P}^{3}\right)$ of Prolagus calpensis from ACB1 shows a morphology which is very similar to that of the neotype of this species from Rosia Bay (early Pleistocene, Gibraltar; LópezMartínez and Thaler, 1975) and to the samples from the late Pliocene of Moreda (Granada) and Illes Medes (Girona; LópezMartínez, 1989). However, as a difference with the material from Rosia Bay and Illes Medes, the third lower premolar $\left(\mathrm{P}_{3}\right)$ from this site does not display any labial cut on the anteroconid. This feature is also observed in some $P_{3}$ from Castelldefels and Cova de Gràcia (López-Martínez, 1989). The size of the $P_{3}$ also falls within the field of variability of Prolagus from these sites. On the other hand, Oryctolagus sp. is represented by $1 \mathrm{~s}$ upper premolar $\left(\mathrm{P}^{2}\right)$, one third lower premolar $\left(P_{3}\right)$, one lower molar $\left(M_{1}\right)$, three right talus, one right calcaneus and one left calcaneus, and a juvenile femur. The teeth and postcranial remains of ACB1 are different from those of Oryctolagus lacosti (De Marfà and Mein, 2007), but might be related to Oryctolagus laynensis (López-Martínez, 1977), Oryctolagus burgi (Nocchi and Sala, 1997a, 1997b) and Oryctolagus giberti (De Marfà, 2008). However, the morphology of the teeth fall within the field of variability of Oryctolagus cuniculus, as it is also the case for their size (Callou, 1997). Therefore, this sample is referred to as Oryctolagus sp. The identification in ACB1 of a member of Oryctolagus which closely resembles $O$. cuniculus indicates that the differentiation of the current species may have taken place in the early Pleistocene, and not in the middle Pleistocene as has been assumed. 


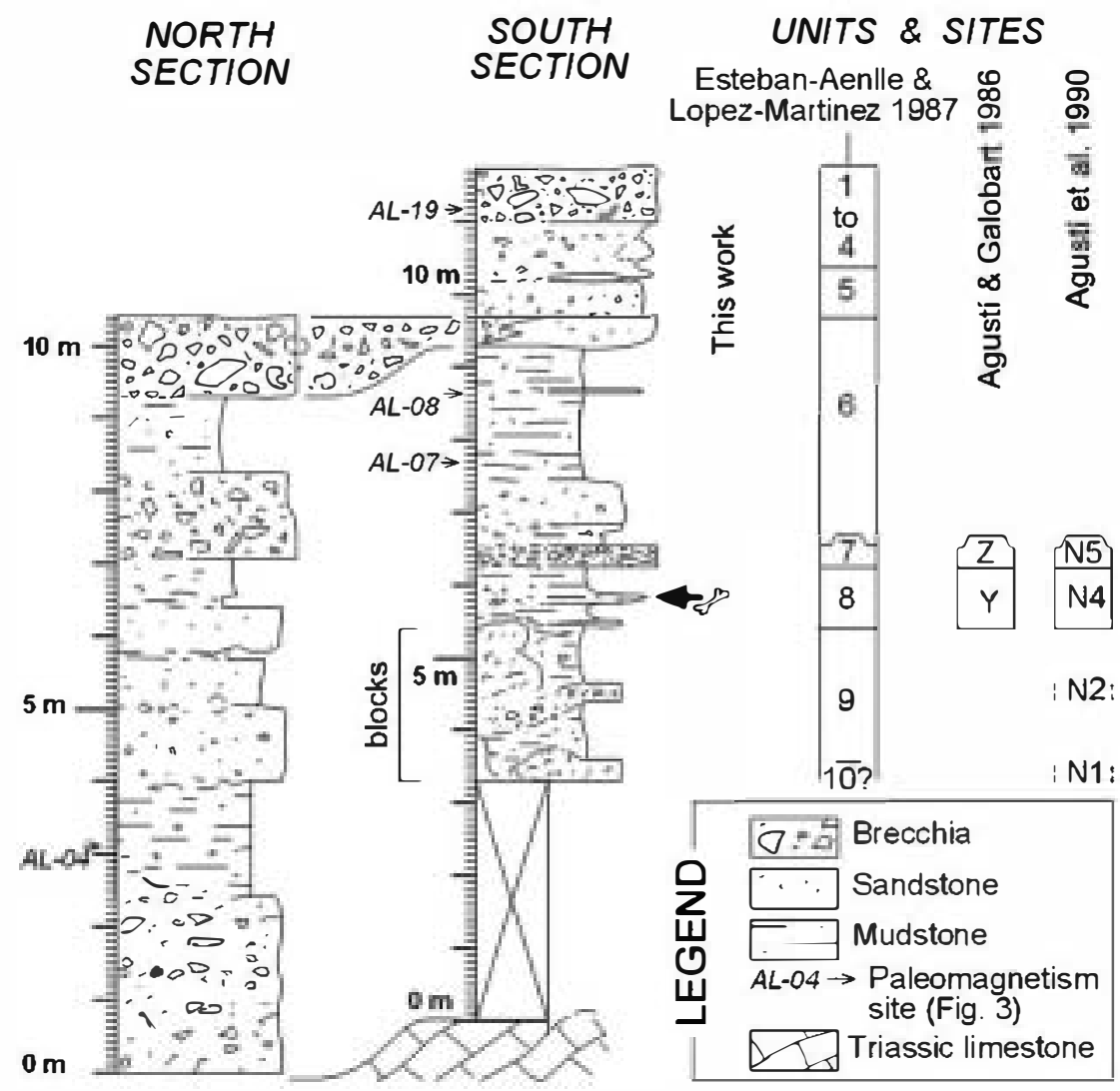

Fig. 2. Almenara-Casablanca 1 section with stratigraphic units according to several authors.

As with other small mammals, insectivores in ACB1 are also very diverse (Table 2), and include Talpa cf. fossilis, Desmana aff. inflata, Myosorex meini, Sorex minutus, Sorex sp., Beremendia fissidens and Petenyia hungarica (Furió, 2007a). The soricid assemblage is the richest one known in Spain for ages close to the Plio-Pleistocene boundary, and includes some infrequent forms in the southwest of Europe, such as Petenyia hungarica and Beremendia fissidens. Apart from ACB1, Petenyia has only been found in Spain in the early Villanyian localities (MN 16) of Moreda and Tollo de Chiclana 13, which may be a consequence of the particular climatic and ecological conditions which were present in southern Europe at this time interval (Minwer-Barakat et al., 2010). A recent paleobiological analysis has shown that Beremendia fissidens was able to survive in different kind of environments, even in unpredictable ones (Furió et al., 2010).

Regarding the bat representation, although a high abundance of remains is observed in $\mathrm{ACB} 1$, only three genera (Rhinolophus, Myotis and Miniopterus) and nine species are represented in the material (Table 2), a lower number than in ACB 4. The assemblage is dominated by the vespertilionids, Miniopterus being the best represented genus in number of remains, followed by Myotis. Among the rhinolophids, the middle-sized species $R$ euryale is somewhat more abundant than the large $R$ ferrumequinum, while the smallest species, $R$ hipposideros, is represented by very few remains. As a whole, the ACB 1 assemblage presents a higher proportion of vespertilionid remains than would be expected for a karst site.

As noted for ACB 4, the representation of amphibians, squamates and chelonids in $\mathrm{ACB} 1$ is also very diverse (Table 3), including anurans (Discoglossus, Pelodytes, Bufo and Pelophylax) amphisbaenids (Blanus cinereus), agamids, gekkonids (Tarentola), scincids (Chalcides $\mathrm{cf}$. bedriagai), anguids (Dopasia), lacertids (Timon and Podarcis/Psammodromus), colubrids (Natrix maura, M. monspessulanus and Rhinechis scalaris) and viperids (Vipera latasti).
Chelonids are represented by testudinids (Testudo sp. and Testudinidae indet.) and emydids (Jiménez-Fuentes, 1985). ACB 1 records the last occurrence of agamids in the Iberian Peninsula. Thus, no record of this group has been reported so far in other early Pleistocene localities from Europe. Most probably, the warm and dry conditions of Spain and southern France favoured their persistence in the earliest Pleistocene, as indicated by their frequent presence in a number of karst sites from these areas (Bailon, 1987, 1989, 1991a; Blain, 2005, 2009; Bailon and Blain, 2007; Agustí et al., 2009). After that, the set of climatic events linked to the transition between the earliest and the early Pleistocene at around $1.8 \mathrm{Ma}$, probably led to the final disappearance of the family in the European latitudes. Similarly, the presence of Dopasia at ACB 4 and ACB 1 suggests a gradual retreat of this genus towards the south of the Iberian Peninsula. Dopasia (formerly Ophisaurus sensu lato) belongs to an Eurasian and African group, and has been noted in the late Pliocene sites of Balaruc II, in southern France, and Illes Medes in northeastern Spain (Bailon, 1991a). It is still present in the late early Pleistocene sites of Quibas (Mancheño et al., 2009) and Barranco León (Blain, 2005, 2009; Bailon and Blain, 2007). Barranco León probably corresponds to the last occurrence of Dopasia in Europe, as this genus is already absent in the late early Pleistocene site of Cueva Victoria, also in southern Spain (Blain et al., 2008). The gradual retreat of the range of Dopasia was probably caused by the climatic deterioration that took place across the late Pliocene and the early Pleistocene (Blain, 2005, 2009; Bailon and Blain, 2007).

As happened with ACB 4, levels equivalent to ACB 1 are present in the sections of Zújar and Galera in the Guadix-Baza Basin (Agustí et al., 1997, 2001 b, 2010; Oms et al., 1999). As in the case of ACB 1, all these levels are characterized by the presence of the arvicolid species Kislangia gusii (Agustí et al., 1993b). In order to achieve a better constraint and correlation of the ACB 1 with other sites of similar age, a paleomagnetic analysis was carried out in this section 
(Fig. 2). A preliminary study after sampling 20 levels scattered throughout the north and south outcrops was developed in order to observe the general paleomagnetic features. Sampling was carried out with an electric drill used to obtain fine grained lithologies (basically red mudstones). One or two samples per level were demagnetized by using thermal stepwise demagnetization. Measuring was carried out with a shielded triaxial cryogenic magnetometer (2G). Demagnetization involved from 11 to 15 steps, from room temperature up to $600{ }^{\circ} \mathrm{C}$ (Fig. 3). A bridge susceptibilimeter was used to detect any sudden susceptibility variation during all the process. A rather stable demagnetization behavior was observed, displaying up to three components. First, a viscous temperature was generally observed and fully demagnetized at temperatures below $150{ }^{\circ} \mathrm{C}$. A low temperature component was generally found and demagnetized between 150 and around $350{ }^{\circ} \mathrm{C}$. At higher temperatures a third component directed to full demagnetization was always present. A general stable demagnetization was observed, but in some cases high temperature component might display a non-consistent orientation (such as being south directed and upwards plunging or vice-versa). This could be the result of removed blocks (a fact sometimes difficult to asses) or/ and to an acquisition processes here not studied. In any case, not a single normal polarity is observed in the sampled materials. All consistent polarities in the Almenara-Casablanca cave-infilling were clearly reversed.

The observed reverse polarity perfectly fits the results which have been obtained for the biostratigraphically equivalent levels of the sections of Galera and Zújar in the Guadix-Baza Basin. Therefore, the levels of Galera 2 and Zújar 14 (Agustí et al., 1993a,b, 1997, $2001 \mathrm{~b})$ again characterized by the presence of the arvicolid Kislangia gusii, are placed within the geomagnetic chron $2 \mathrm{r}$. The reverse polarity of the section of Almenara-Casablanca 1 can be, therefore, correlated with this chron and a lower Matuyama, preOlduvai age can be inferred for the large and small mammal succession from this site.

\section{Almenara-Casablanca 3 (ACB 3, late early Pleistocene)}

This small deposit was discovered during investigations in 1984 and has provided a diversified small vertebrate assemblage. The rodent association includes a diversified list of arvicolids (Mimomys aff. savini, Allophaiomys chalinei, Iberomys aff. huescarensis, Pliomys episcopalis), cricetids (Allocricetus bursae duraciensis), murids (Apodemus flavicollis, Apodemus mystacinus, Castillomys rivas) and glirids (Eliomys quercinus helleri; Agustí and Galobart, 1986; Agustí,
1991; Martín-Suárez and Mein, 1991; Santos-Cubedo, 2003). This association indicates a late early Pleistocene age.

Lagomorphs are represented by Prolagus sp. and Oryctolagus sp. With respect to Prolagus, there is only a third lower premolar $\left(\mathrm{P}_{3}\right)$ which presents peculiar features and does not allow a specific assignment. In a similar way, the leporid from ACB3 cannot be assigned to any species, provided the scarcity of the available material. The morphology of the $\mathrm{P}_{3}$ permits its assignment to genus Oryctolagus (De Marfà, 2009).

The insectivore and bat representation includes Crocidura sp., Sorex cf. araneus, Neomys sp., Myotis blythi and Chiroptera indet (Furió, 2007a; Furió et al., 2005). Neomys is represented by just an upper incisor, two fourth upper premolars, one second upper molar, three third lower molars and a fragment of a hemimandible, so its specific ascription is quite difficult. However, this is enough to determine it as the oldest justified record of the genus in Spain (Furió, 2007a). The presence of Crocidura is significant from a biostratigraphical point of view, as Crocidura kornfeldi was the first crocidurinae which arrived in Europe (Reumer, 1984; RzebikKowalska, 1995). The first occurrences in this continent correspond to early Pliocene sites, but the genus did not arrive in the Iberian Peninsula until the early Pleistocene (Furió, 2007b; Furió et al., 2007). In Sima del Elefante, one of the oldest occurrences of the genus in Spain, the species present is actually $C$. kornfeldi, and the form present in ACB 3 is fairly similar in morphology, but not in its measurements, to this same species (Rofes and Cuenca-Bescós, in press).

The amphibian and squamate representation is mainly composed of anurans (cf. Discoglossus, Pelobates cultripes, Pelodytes cf. punctatus, Bufo bufo, Bufo sp. and Pelophylax cf. perezi), amphisbaenids (Blanus cinereus), lizards (Chalcides cf. bedriagai and Lacertidae indet.) and a varied list of snakes (Natrix natrix, $C$. girondica, M. monspessulanus, Rh. scalaris and V. latasti). Exotic elements such as agamids or anguids are absent (Blain et al., 2007; Bailon and Blain, 2007; Agustí et al., 2009), and also the gekkonid Tarentola that may suggest a probable cooling of the climate in relation with ACB 4 and ACB 1.

The arvicolid association is close to those of a number of sites of late early Pleistocene age. The presence of Iberomys aff. huescarensis indicates an age younger than the levels of Fuente Nueva 3 and Barranco León, in the Guadix-Baza Basin, which record the oldest human evidence in Western Europe (Martínez-Navarro et al., 1997; Oms et al., 2000; Agustí and Madurell, 2003; Toro et al., 2003). ACB 3 can be correlated with other somewhat younger levels in that basin, such as Huéscar 1, Puerto Lobo and Loma Quemada (Mazo

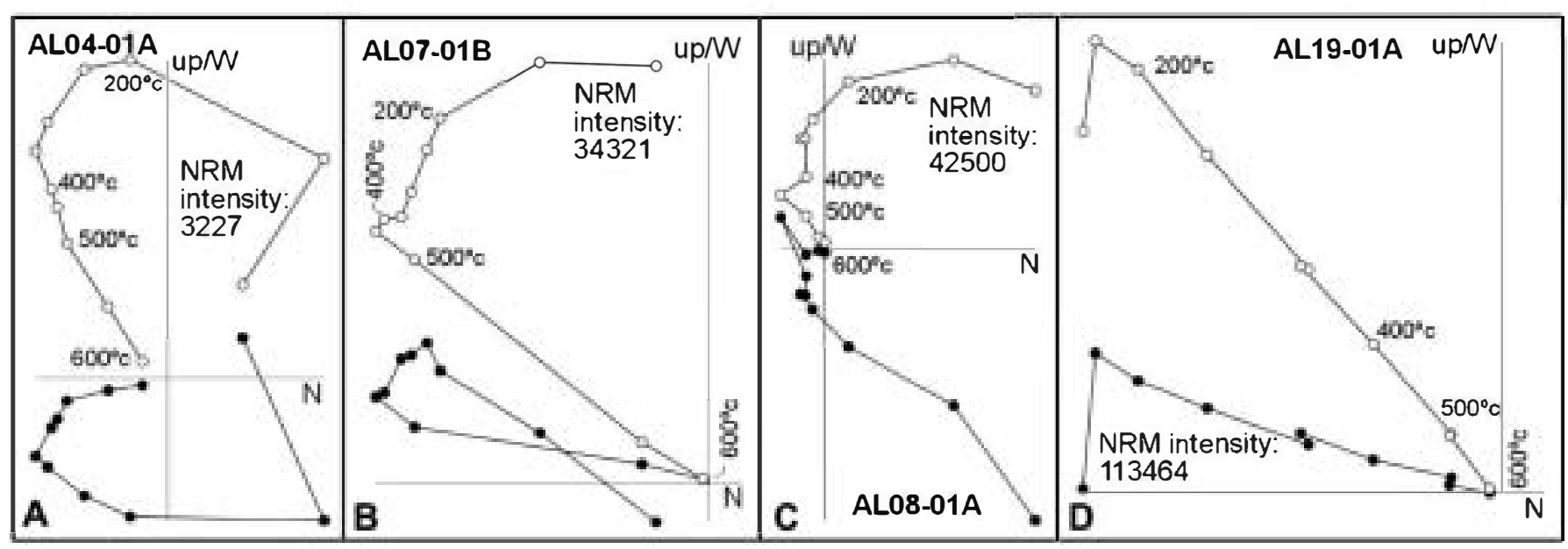

Fig.3. Orthogonal demagnetization plots for selected geomagnetic samples from Almenara-Casablanca 1. A, B, 
et al., 1985; Agusti, 1986; Agustí and Moyà-Solà, 1991). A similar association is also found in other sites with human presence, such as Sima del Elefante (Cuenca-Bescós et al., 2001) and Cueva Victoria (Carbonell et al., 1981; Alcalde et al., 1981; Agustí, 1982; Gibert et al., 2006; Blain et al., 2008). These localities share with ACB 3 the presence of Allophaiomys chalinei, a typical late early Pleistocene microtine from the Iberian Peninsula (Alcalde et al., 1981; Agustí, 1992). A combination of biostratigraphy (Agustí, 1982) and magnetostratigraphy (Gibert et al., 2006) in Cueva Victoria placed this site just below the Jaramillo subchron, with an estimated age of 1.07 Ma (Blain et al., 2008). Most probably, a similar age can be assumed for ACB 3.

\section{Concluding remarks: the paleoenvironmental succession of the Almenara-Casablanca complex}

The paleoclimatic data from Almenara-Casablanca $M$ are too scarce to infer detailed climatic parameters, although sub-desert conditions linked to northward extension of north-African biotas due to the Messinian Salinity Crisis can be inferred from the high diversity of myocricetodontines and gerbils (Myocricetodon jaegeri, Calomyscus sp., Debruijnimys almenarensis, Pseudomeriones abbreviatus) and the low insectivore diversity.

Late Pliocene environments in the area were very different, as shown by the site of Almenara-Casablanca 4. The application of the Mutual Climatic Range (MCR) method to the amphibian and squamate associations, based on the intersection of their recent distributions, permits to estimate a number of climatic parameters (Blain et al., 2009; Agustí et al., 2009). According to this method, mean annual temperature (MAT) for ACB 4 can be estimated to $17.1 \pm 1.5^{\circ} \mathrm{C}\left(+0.1^{\circ} \mathrm{C}\right.$ compared to present $)$, with temperature of the coldest month (MTC) at $9.1 \pm 2.4^{\circ} \mathrm{C}\left(-1.4{ }^{\circ} \mathrm{C}\right.$ compared to present) and temperature of the warmest month (MTW) at $24.6 \pm 1.1{ }^{\circ} \mathrm{C}$ $\left(+0.1{ }^{\circ} \mathrm{C}\right.$ compared to present). Mean annual precipitation (MAP) is estimated as $711 \pm 229 \mathrm{~mm}$ ( $+261 \mathrm{~mm}$ compared to present). These data are in concordance with the occurrence in ACB 4 of exotic reptiles such as the agamid lizards, which currently live under climate with MAT higher than $15{ }^{\circ} \mathrm{C}$, and anguid lizards (Dopasia), which suggest more humid environmental conditions than today. They are also consistent with the presence of the red-toothed shrews Deinsdorfia and Sorex minutus, which use to live in moist local environments (Reumer, 1984). Moreover, the insectivore assemblage is largely dominated by the white-toothed crocidosoricine shrew Myosorex, which indicates rather warm conditions. Within moles, the digging forms of the genus Talpa are indicative of soft soils with a constant degree of humidity, while the diving forms of the genus Desmana are indicative of the existence of water masses in the surroundings. Among the bats, although the vespertilionids are represented by few remains, the co-existence of Myotis emarginatus, Plecotus sp. and Eptesicus sp. indicates a quite diverse environment in the vicinity of the locality, with less arid conditions than today and a certain development of wooded areas.

With respect to Almenara-Casablanca 1, the application of the MCR method to the amphibian and squamate association shows that MAT are estimated to $16.5 \pm 2.4{ }^{\circ} \mathrm{C}\left(-0.5{ }^{\circ} \mathrm{C}\right.$ compared to present $)$, with MTC at $9.0 \pm 4.0^{\circ} \mathrm{C}\left(-1.5^{\circ} \mathrm{C}\right.$ compared to present $)$ and MTW at $24.4 \pm 1.4{ }^{\circ} \mathrm{C}\left(-0.1{ }^{\circ} \mathrm{C}\right.$ compared to present $)$. MAP are calculated as $794 \pm 184 \mathrm{~mm}(+344 \mathrm{~mm}$ compared to present). As in the case of ACB 4, these data are confirmed by the insectivore association, characterized by the co-occurrence of aquatic and burrower moles and the high diversity of shrews, which suggests the dominance of warm conditions with a high degree of humidity in the environment and the presence of some kind of open waters nearby.

In the case of Almenara-Casablanca 3, the application of the MCR method to the amphibian and squamate association suggests that
MAT was equal to $14.9 \pm 3.6{ }^{\circ} \mathrm{C}\left(-2.1{ }^{\circ} \mathrm{C}\right.$ in relation with present), with MTC equal to $7.3 \pm 4.0^{\circ} \mathrm{C}\left(-3.2^{\circ} \mathrm{C}\right.$ in relation with present $)$ and MTW equal to $23.9 \pm 2.3^{\circ} \mathrm{C}\left(-0.6^{\circ} \mathrm{C}\right.$ in relation with present). MAP was $683 \pm 125 \mathrm{~mm}(+233 \mathrm{~mm}$ in relation to present). Among the Soricidae, the overwhelming dominance of Crocidura remains (representing around 90\% of the soricid assemblage) suggests relatively dry environmental conditions. However, the anecdotic presence of Sorex and Neomys could be indicative of a small peak of moisture in time or space in the neighbouring area. Currently, the assemblage of these three soricids looks more similar to a recent community thanACB 1 . The area is nowadays dominated by a typical Mediterranean climate. Therefore, the conditions during most of the year are too dry for red-toothed shrews, the area being only currently inhabited by white-toothed shrews of the genera Crocidura and Suncus.

Such MCR intersections for the various localities of the Almenara-Casablanca karst complex suggest a MAT somewhat similar to the present during the late Pliocene-earliest Pleistocene, and cooler at the end of the early Pleistocene $\left(-2.1^{\circ} \mathrm{C}\right.$ in ACB 3). Continentality was slightly stronger, as winters were colder (in particular in $A C B 3$, with $-3.2{ }^{\circ} \mathrm{C}$ ) but summer temperatures remained unchanged. The values for rainfall (MAP) were not so strongly different from those of today, although the values indicate more humid conditions than today for the late Pliocene and the earliest Pleistocene.

\section{Aclenowledgements}

This paper has been supported by projects SGL2009-7896 (Spanish Ministry of Science and Innovation) and SGR2009-324 (Generalitat de Catalunya). We acknowledge also the support from Scientific-technical services from Barcelona University (Paleomagnetism Laboratory, Institute of Earth Sciences, CSIC-UB), the Department d'Universitats, Recerca i Societat (Generalitat de Catalunya) and the Fons Social Europeu. We are also grateful to Gloria Cuenca-Bescós, Eulàlia García and Cristina Díaz. Finally, we acknowledge the comments by Salvador Bailon and Raef MinwerBarakat, which considerably improved the paper.

\section{References}

Agusti, J., 1982. Los Roedores (Mammalia) del Pleistoceno inferior de la "Cueva Victoria" (Murcia, España). Endins 9, 49-55.

Agusti, J., 1986. Synthèse biostratigraphique du Plio-Pleistocène de Guadix-Baza (province de Granada, Sud-Est de I'Espagne). Geobios 19, 505-510.

Agusti, J., 1989. On the peculiar distribution of some muroid taxa in the Western Mediterranean. Bolletino della Società Paleontológica Italiana 28 (2-3), $147-154$.

Agusti, J., 1990. The Miocene Rodent Succession in Eastern Spain: a zoogeographical appraisal. In: Lindsay, E.H., Fahlbusch, V., Mein, P. (Eds.), European Neogene Mammal Chronology. Plenum Press, New York, pp. 375-404.

Agusti, J., 1991. Gerbilidés fossiles d'Europe occidentale. In: Le Berre, Guelte (Eds.), Le Rongeur et I'Espace. R Chabaud, Paris, pp. 177-182.

Agusti, J., 1992. The Allophaiomys complex in Southern Europe. Geobios 25 , $133-144$.

Agusti, J., Casanovas-Vilar, I., 2003. Neogene gerbils from Europe. Deinsea 10, 13-21 (Rotterdam)

Agusti, J., Galobart, A., 1986. La sucesión de micromamíferos en el complejo cárstico de Casablanca (Almenara, Castellón): Problemática biogeográfica. Paleontologia i Evolució 20, 57-62.

Agusti, J., Llenas, M., 1996. The late Turolian muroid rodent succession in eastern Spain. Acta Zoologica Cracoviensia 39 (1), 47-56

Agusti, J., Madurell, J., 2003. Los arvicólidos (Muroidea, Rodentia, Mammalia) del Pleistoceno inferior de Barranco León y Fuente Nueva 3 (Orce, Granada). In: Toro, I., Agustí, J., Martínez-Navarro, B. (Eds.), El Pleistoceno inferior de Barranco León y Fuente Nueva 3, Orce (Granada). Arqueología Monografías 17, pp. 105-114.

Agusti, J., Moyà-Solà, S., 1991. Les faunes de mammifères du Pléistocène inférieur et moyen de L'Espagne: implications biostratigraphiques. L'Anthropologie 95 , $753-764$.

Agusti, J., Blain, H.-A., Cuenca-Bescós, G., Bailon, S., 2009. Climate forcing of first hominid dispersal in Western Europe. Journal of Human Evolution 57, 815-821. 
Agustí, J., Blain, H.-A., Furío, M., de Marfá, R, Santos-Cubedo, A., 2010. The early Pleistocene small vertebrate succession from the orce region (Guadix-Baza Basin, SE Spain) and its bearing on the first human occupation of Europe. Quaternary International 223-224, 162-169.

Agustí, J., Cabrera, L., Garcés, M., Krijgsman, W., @ms, ๑., Parés, J.M., 2001a. A calibrated mammal scale for the Neogene of Western Europe. State of the Art. Earth Science Reviews 52, 247-260.

Agustí, J., Castillo, C., Galobart, A., 1993a. Heterochronic evolution in the late Pliocene early Pleistocene Arvicolids of the Mediterranean area. Quaternary International $19,51-56$.

Agusti, J., Galobart, A., Martin Suárez, E., 1993b. Kislangiagusii sp. nov., a newarvicolid (Rodentia) from the Late Pliocene of Spain. Scripta Geologica 103, 119-134.

Agustí, J., Garcés, M., Krijgsman, W., 2006. Evidence for African-Iberian exchanges during the Messinian in the Spanish mammalian record. Palaeogeography, Palaeoclimatology, Palaeo ecology 238, 5-14.

Agustí, J., Moyà Solà, S., Pons Moyà, J., 1986. Venta Micena (Guadix Baza basin, South Eastern Spain): its place in the Plio Pleistocene Mammal succession in Europe. Geologica Romana 25, 33-62.

Agustí, J., Moyà Solà, S., Pons Moyà, J., 1987. La sucesión de Mamíferos en el Pleistoceno inferior de Europa: proposición de una nueva escala bioestratigráfica. Paleontologia i Evolució, Memòria Especial 1, 287-295.

Agustí, J., @ms, ๑., Garcés, M., Parés, J.M., 1997. Calibration of the late Pliocene early Pleistocene transition in the continental beds of the Guadix Baza Basin (South Eastern Spain). Quaternary International 40, 93-100.

Agustí, J., @ms, •., Remacha, E., 2001b. Long Plio-Pleistocene terrestrial record of climate change and mammal turnover in Southern Spain. Quaternary Research 56, 411-418.

Alcalde, G., Agusti, J., Villalta, J.F., 1981. Un nuevo Allophaiomys (Arvicolidae, Rodentia, Mammalia) en el Pleistoceno inferior del Sur de España. Acta Geologica Hispanica 16 (4), 203-205.

Augé, M., 2005. Evolution des lézards du Paléogène en Europe. Mémoires du Muséum national d'Histo ire naturelle 192, 1-369.

Bailon, S., 1987. Les plus récents Agamidae fossiles de l'Europe occidentale et centrale (Pliocène supérieur de Seynes, France). Bulletin de la Société Herpétologique de France $42,1-4$.

Bailon, S., 1989. Les Amphibiens et les Reptiles du Pliocène supérieur de Balaruc ll (Hérault, France). Palaeovertebrata 19, 7-28.

Bailon, S. 1991a. Amphibiens et reptiles du Pliocène et du Quaternaire de France et d'Espagne: mise en place et évolution des faunes. Thèse 3ème cycle, Université de Paris VII, 499 p., 89 pls, Unpublished.

Bailon, S., 1991b. Le genre Malpolon (Serpentes, Colubridae) dans les gisements français. Bulletin de la Société d'Herpétologie Française 58, 1-10.

Bailon, S., Blain, H.-A., 2007. Faunes de reptiles et changements climatiques en Europe occidentale autour de la limite Plio-Pléistocène. Quaternaire 18, 55-63.

Blain, H.-A. 2005. Contribution de la paléoherpétofaune (Amphibia \& Squamata) à la connaissance de l'évolution du climat et du paysage du Pliocène supérieur au Pléistocène moyen d'Espagne. Thèse de doctorat du Muséum national d'Histo ire naturelle, Département de Préhistoire, 402 p., 67 pls, Unpublished.

Blain, H.-A., 2009. Contribution de la paléoherpétofaune (Amphibia \& Squamata) à la connaissance de l'évolution du climat et du paysage du Pliocène supérieur au Pléistocène moyen d'Espagne. Treballs del Museo de Geología de Barcelona 16, $9-170$.

Blain, H.-A., Bailon, S., Agustí, J., 2007. Anurans and squamate reptiles from the latest early Pleistocene of Almenara-Casablanca-3 (Castellón, East of Spain). Systematic, climatic and environmental considerations. Geodiversitas 29, 269-295.

Blain, H.-A., Bailon, S., Agustí, J., 2008. Amphibians and squamate reptiles from the latest early Pleistocene of Cueva Victoria (Murcia, southeastern Spain, SW Mediterranean): paleobiogeographic and paleoclimatic implications. Geologica Acta 6, 345-361.

Blain, H.-A., Bailon, S., Cuenca-Bescós, G., Arsuaga, J.L., Bermı̂dez de Castro, J.M., Carbonell, E., 2009. Long-term climate record inferred from Early-Middle Pleistocene amphibian and squamate reptile assemblages at the Gran Dolina cave, Atapuerca, Spain. Journal of Human Evolution 56, 55-65.

Callou, C., 1997. Diagnose différentielle des principaux éléments squelettiques du Lapin (Oryctolagus) et du Lièvre (Lepus) en Europe occidentale. Fiches d'ostéologie animale pour l'archéologie, Série B. Centre de Recherches Archéologiques, Valbonne.

Carbonell, E., Estévez, J., Moyà, S., Pons, J., Agustí, J., Villalta, J.F., 1981. Cueva Victoria (Murcia, España): lugar de ocupación humana más antiguo de le Península lbérica. Endins 8, 47-57.

Carranza, S., Arnold, E.N., Pleguezuelos, J.M., 2006. Phylogeny, biogeography and evolution of two Mediterranean snakes, Malpolon monspessulanus and Hemorrhois hippocrepis, using mtDNA sequences. Molecular Phylogenetics and Evolution 40, 532-546.

Cuenca-Bescós, G. Canudo, J1. Laplana, C, 2001. La séquence des rongeurs (Mammalia) des sites du Pléistocène inférieur et moyen d'Atapuerca (Burgos, Espagne). L'Anthropologie 105, 115-130.

De Marfà, R, 2008. Oryctolagus giberti n. sp. (Lagomorpha, Mammalia) du Pléistocène inférieur de Cueva Victoria (Murcia, Espagne). Comptes Rendus Palevol 7 (5), 305-313.

De Marfà, R 2009. Els lagomorfs (•. Lagomorpha, Cl. Mammalia) del Pliocè i el Pleistocè europeus. Tesi Doctoral. Universitat de Barcelona. 206 pp.

De Marfà, R, Mein, P., 2007. Révision d'Oryctolagus lacosti (Lagomorpha, Mammalia) du Pliocène supérieur de Perrier (Auvergne,France). Comptes Rendus Palevol 6 $327-334$.
Esteban Aenlle J., López Martinez, N 1987. Les atvicolidés (Rodentia, Mammalia) du Villanyen récent de Casablanca 1 (Castellón, Espagne). Geobios 20 (5), 591-623.

Furió, M. 2007a. Los Insectivoros (Soricomorpha, Erinaceomorpha, Mammalia) del Neógeno superior del Levante Ibérico. Tesis Doctoral. Universitat Autònoma de Barcelona. $299 \mathrm{pp}$

Furió, M., 2007b. La llegada de la musaraña de dientes blancos Crocidura (Soricidae Insectivora, Mammalia) a la Península lbérica. In: Cambra Moo, @., Martinez Pérez, C., Chamero Macho, B., Escaso Santos, F., de Esteban Trivigno, S., Marugán Lobón, J. (Eds.), Cantera Paleontológica, vol. 53. Ediciones Provinciales, Cuenca, pp. 193-206.

Furió, M., Mein, P., 2008. A new species of Deinsdorfia (Soricidae, Insectivora Mammalia) from the Pliocene of Spain. Comptes Rendus Pale vol. 7, 347-359.

Furió, M., Agustí, J., Mouskhelishvili, A., Sanisidro, ๑., Santos-Cubedo, A., 2010. The paleobiology of the extinct venomous shrew Beremendi (Soricidae, Insectivora, Mammalia) in relation to the geology and paleoenvironment of Dmanisi (Early Pleistocene, Georgia). Journal of Vertebrate Paleontology 30 (3).

Furió, M., Santos-Cubedo, A., Blain, H.-A., Blaya, E., Casanovas-Vilar, I., Madurell, J., Alba, D.M., 2005. Síntesis sobre las faunas fósiles del complejo cárstico de Almenara-Casablanca (Castellón). In: Meléndez, G., Martinez-Pérez, C., Ros, S., Botella, H., Plasencia, P. (Eds.), Miscelánea Paleontológica, vol. 6. Publicaciones del Seminario de Paleontología de Zaragoza SEPAZ, pp. 273-286.

Furió, M., Santos-Cubedo, A., Minwer-Barakat, R, Agustí, J., 2007. Evolutionary history of the African soricid Myosorex (Insectivora, Mammalia) out of Africa Journal of Vertebrate Paleontology 27 (4), 1018-1032.

Freixes, A., 2004. Informe Geológico. In: Gusi, F. (Ed.), Roedores, Monos, Caballos y Ciervos. Colección de Prehistoria y Arqueología castellonenses. Servei d'Invesgacions Arqueològiques i Prehistòriques, Diputació de Castelló, pp. 37-41.

Gibert, J., Gibert, L., Fernández-Canyadell, C., Robot, F., Iglesias, A., Gibert, P., 2006. Cueva Victoria: Geología, Paleontología, restos humanos y edades. Memorias de Arqueología Región de Murcia 14, 37-62.

Gil, E., Sesé, C., 1984. Micromamíferos del nuevo yacimiento Villafranquiense de Casablanca I (Almenara, Prov. de Castellón). Estudios Geológicos 40, 243-249.

Gil, E., Sesé, C., 1985. Micromamíferos (Insectivora, Rodentia y Lagomorpha) de nuevo yacimiento Villafranquiense de Casablanca B (Almenara, Prov. de Castellón). Estudios Geológicos 41 945-501.

Ginés, A., Pons Moyà, S., 1986. Aproximación al origen del yacimiento paleon tológico del Pleistoceno inferior de Casablanca I (Almenara, Castellón). Endins $12,41-49$.

Gusi, F., Gibert, J., Agustí, J., Maroto, J., 1986. El yacimiento Plio-Pleistocenico Casa Blanca 1 de Almenara (Castellón, España). The World Archaeological Congress, Southampton, pp. $1-8$

Jiménez-Fuentes, E., 1985. Quelonios fósiles del Plioceno terminal de Almenara (Castellón). Stvdia Geologica Salmanticensia 21, 125-151.

Köhler, M., Moyà-Solà, S., Martínez Alba, D., 2000. Macaca (Primates, Cercopithecidae) from the Late Miocene of Spain. Journal of Human Evolution 38 $447-452$

Krijgsman, W., Hilgen, F.J., Raffi, I., Sierro, F.J., Wilson, D.S., 1999. Chronology, causes and progression of the Messinian salinity crisis. Nature 400, 652-655

López Martínez, N., Thaler, L, 1975. Biogéographie, évolution et compléments à la systématique du groupe d'ochotonidés Piezodus-Prolagus (Lagomorpha) Bulletin de la Société Géologique de France 7 (17), 850-866

López Martinez, N. 1977. Revisión sistemâtica y bioestratigrâfica de los lagomorfos (Mammalia) del Terciario y Cuaternario de España. Tesis doctoral, Universidad de Madrid, $469 \mathrm{p}$

López Martínez, N., 1989. Revisión sistemática y bioestratigráfica de los lagomorfos (Mammalia) del Terciario y Cuaternario de España. Memoria del Museo Paleontológico de la Universidad de Zaragoza 3 (3)

Lourens, L., Hilgen, F., Shackleton, N.J., Laskar, J., Wilson, J., 2004. Orbital tuning calibrations and conversions for the Neogene period. In: Gardstein, F, ogg J. (Eds.), A Geologic Time Scale. Cambridge University Press, Cambridge.

Macey, J.R, Schulte, J.A., Larson, A., Tuniyev, B.S., Orlov, N., Papenfuss, T.J., 1999 Molecular phylogenerics, tRNA evolution, and historical biogeography in Anguid Lizards and related taxonomic families. Molecular Phylogenetics and Evolution 12, 250-272

Madurell-Malapeira, J., Santos-Cubedo, A, Marmi, J, 2009. Idest European occurrence of Meles (Mustelidae, Carnivora) from the Middle Pliocene (MN16) of Almenara-Casablanca-4 karst site (Castellón, Spain). Journal of Vertebrate Paleontology 29 (3), 961-965.

Mancheño, M.A., Agustí, J., Blain, H.-A., Laplana, C., Sevilla, P., 2009. The small vertebrate association from Quibas (Murcia, Spain) and the environmental context of the early human dispersal in Western Europe. Journal of Vertebrate Paleontology 29 (3), 141A

Martin-Suárez, E., Freudenthal, M., Krijgsman, W., Rutger-Fortuin, A., 2000. On the age of the continental deposits of the Zorreras Member (Sorbas Basin, SE Spain) Geobios 33, 505-512.

Martin-Suárez, E., Mein, P., 1991. Revision of the genus Castillomys (Muridae Rodentia). Scripta Geologica 96, 47-81.

Martinez-Navarro, B., Turq. A., Agustí, J., oms, •., 1997. Fuente Nueva-3 (Orce, Granada, Spain) and the first human occupation of Europe. Journal of Human Evolution 33, 611-620

Mazo, A Sesé, C., Ruiz-Bustos, A Peña, J 1985 Geología y paleontología de los yacimientos plio-pleistocénicos de Huéscar (Depresión de Guadix-Baza, Granada). Estudios Geológicos 41, 467-493.

Minwer-Barakat R, García-Alix, A. Agustí, J. Martín-Suárez, E. Freudenthal M. 2009. The micromammal fauna from Negratin-1 (Guadix Basin, Southern 
Spain): new evidence of African-Iberian mammal exchanges during the late Miocene. Journal of Paleontology 83 (6), 854-879.

Minwer-Barakat, R., García-Alix, A., Martín-Suárez, E., Freudenthal, M., 2010. Soricidae (Soricomorpha, Mammalia) from the Pliocene ofTollo de Chiclana (Guadix Basin, Southern Spain). Journal of Vertebrate Paleontology 30 (2), 535-546.

Nocchi, G., Sala, B., 1997a. The fossil rabbit from Valdemino Cave (Borgio Verezzi, Savona) in the context of western Europe Oryctolagini of Quaternary. Palaeovertebrata $26(1-4), 167-187$.

Nocchi, G., Sala, B., 1997b. Oryctolngus burgi n. sp. (Mammalia, Lagomorpha) from the Middle Pleistocene levels of Grotta Valdemino (Borgio Verezzi, Savona north-west Italy). Paleontologia i Evolució 30-31, 19-38.

-ms, ๑., Dinarés, J., Agustí, J., Parés, J.M., 1999. Refinements of the European mammalian biochronology: magnetic polarity record of the Plio-Pleistocene Z1ijjar section, (Guadix-Baza Basin, SE Spain). Quaternary Research 51, 94-103.

- ms, @., Parés, J.M., Martínez-Navarro, B., Agustí, J., Toro, I., Martinez-Fernández, G., Turq, A., 2000. Early human occupation of Western Europe: paleomagnetic dates for two paleolithic sites in Spain. Proceedings of the National Academy of Science of the United States of America 97, 10666-10670.

Pérez Cuevas, A.J., 2004. Informe geomorfológico. In: Gusi, F. (Ed.), Roedores, Monos, Caballos y Ciervos. Colección de Prehistoria y Arqueología castellonenses. Servei d'Investigacions Arqueològiques i Prehistòriques, Diputació de Castelló, pp. 31-35.

Pickford, M., Moyà-Solà, S., Mein, P., 1997. A revised phylogeny of Hyracoidea (Mammalia) based on new specimens of Pliohyracidae from Africa and Europe.
Neues Jahrt 265-288

Reumer, J.W.F., 1984. Ruscinian and early Pleistocene Soricidae (Insectivora, Mammalia) from Tegelen (The Netherlands) and Hungary. Scripta Geologica 73, $1-173$.

Rofes, J., Cuenca-Bescós, G. (in press). Evolutionary history and biogeography of the genus Crocidura (Mammalia, Soricidae) in Europe, with emphasis on Crocidura komfeldi. Mammalian Biology.

Rzebik-Kowalska, B., 1995. Climate and history of European shrews (family Soricidae). Acta Zoologica Cracoviensia 38 (1), 95-107.

Santos-Cubedo, A., 2003. Muiridos (Muridae, Rodentia) del yacimiento Casablanca-3 (Pleistoceno inferior) de Almenara(Castellón, España). In: GusiF(Ed.), Roedores, Monos, Caballos y Ciervos. Colección de Prehistoria y Arqueología castellonenses. Servei d'Investigacions Arqueològiques i Prehistòriques, Diputació de Castelló, pp. 207-208

Soto, E., Morales, J., 1985. Grandes mamíferos del yacimiento villafranquiense de Casablanca I, Almenara (Castellón). Estudios Geológicos 41, 243-249.

Toro, I., Agustí, J., Martínez-Navarro, B. (Eds.), 2003, El Pleistoceno inferior de Barranco León y Fuente Nueva 3, Orce (Granada), vol. 17. Arqueología Monografías, p. 206.

Van den Hoek ostende, L.W., Furió, M., 2005. In: Van den Hoek @stende, L.W., Doukas, C.S., Reumer, J.W.F. (Eds.), The Fossil Record of the Eurasian Neogene Insectivores (Erinaceomorpha, Soricomorpha, Mammalia), Part I Spain, vol. 5. Scripta Geologica Special Issue, Spain, pp. 149-284. 